\title{
A Framework for Fairness Evaluation and Improvement of Urban Green Space: A Case of Wuhan Metropolitan Area in China
}

\author{
Peng Cheng, Min Min *, Weiyan Hu and Anlu Zhang \\ College of Public Administration, Huazhong Agricultural University, Wuhan 430070, China; \\ chengfapeng@webmail.hzau.edu.cn (P.C.); huweiyan@mail.hzau.edu.cn (W.H.); \\ zhanganlu@mail.hzau.edu.cn (A.Z.) \\ * Correspondence: mmin2010@mail.hzau.edu.cn
}

Citation: Cheng, P.; Min, M.; Hu, W.; Zhang, A. A Framework for Fairness Evaluation and Improvement of Urban Green Space: A Case of Wuhan Metropolitan Area in China. Forests 2021, 12, 890 .

https://doi.org/10.3390/f12070890

Academic Editors:

Francesca Rapparini and Rita Baraldi

Received: 3 June 2021

Accepted: 5 July 2021

Published: 7 July 2021

Publisher's Note: MDPI stays neutral with regard to jurisdictional claims in published maps and institutional affiliations.

Copyright: (c) 2021 by the authors. Licensee MDPI, Basel, Switzerland. This article is an open access article distributed under the terms and conditions of the Creative Commons Attribution (CC BY) license (https:// creativecommons.org/licenses/by/ $4.0 /)$.

\begin{abstract}
Urban green space (UGS) provides a wide range of ecosystem services for human beings. The fairness of UGS distribution has important implications for sustainable urban development and human well-being. However, many current studies on green space fairness are limited to within specific cities, and UGS fairness in rapidly developing metropolitan areas is still largely neglected. This study quantifies the change in green space fairness in the Wuhan metropolitan area from 2000 to 2020 based on a long time series of land cover and population spatial distribution products. We incorporated green space types and population distribution into the fairness evaluation framework, quantified the value of green space ecosystem services available to people through nested buffers, and analyzed the spatial and temporal variation of green space fairness in the study area based on the Gini coefficient of each city. The results show that the supply of green space services in most cities has shown a trend of "decreasing and then increasing" in the past 20 years. The fairness of green space in three cities has shown an improving trend, and the Gini coefficient in four cities is still above 0.50 in 2020. Based on the current green space and related indicators in each city, we propose future greening policies for each city. The methodology and conclusions of this study will help improve future green space planning recommendations in metropolitan areas and urban agglomerations, thus promoting regional public infrastructure coproduction and sharing.
\end{abstract}

Keywords: urban green space; fairness; Gini coefficient; ecosystem service; Wuhan metropolitan area

\section{Introduction}

Urbanization has become a common phenomenon worldwide. The United Nations predicts that the global urban population will reach nearly 5 billion by 2030, and the metropolitan land area will reach 1.5 million square kilometers [1]. Urban green space (UGS) is an essential component of the urban landscape and the recreation of residents which can be defined as all types of spaces in which a large amount of green vegetation grows in the urban environment [2,3]. Numerous studies have shown that cities with more green space per capita provide more significant health benefits and improve the quality of life of their residents [4-6]. Ecosystem services are life-supporting goods and services obtained directly or indirectly through the structure, processes and functions of ecosystems [7]. Millennium Ecosystem Assessment classifies ecosystem service functions into four major categories: provisioning services, regulating services, cultural services and supporting services [7]. UGS can provide a variety of ecosystem services to cities [8]. The regulation services provided by UGS can mitigate the urban heat island effect $[9,10]$, reduce noise [11,12], improve air quality [13-15], improve soil water storage capacity and groundwater quality [16,17], and resist urban flooding [18]. UGS's provisioning and support services include providing food [19] and improving habitat for various organisms [20]. In addition, UGS's sociocultural services are focused on improving residents' physical 
and mental health and enhancing social cohesion. There is clear evidence that UGS can attract people to participate in physical activity outdoors [21,22], and relieve the stress of living and working. Most studies believed that increasing urban green spaces can promote communication and connection among residents [23]. Other studies have verified UGS can significantly reduce the probability of crime and violence [24]. Although a large number of studies have identified UGS as important public infrastructure and a key aspect affecting human well-being, with the increasing global urbanization and regional differences in the level of economic development, the original UGS can no longer meet the needs of the growing population, and there are significant differences in the green space services available to people $[25,26]$, and these issues pose a tremendous threat to green justice $[27,28]$. Therefore, there is an urgent need to consider the relationship between the supply and demand of green space and population when evaluating the equity of urban green space and formulating UGS fairness promotion policies.

UGS fairness means that urban residents should have equal access to the ecosystem services provided by green spaces, regardless of the city's size, natural endowment, and geographic location. Current research on the UGS fairness can be broadly divided into three analytical perspectives: regional equity based on equal resources, spatial structural equity based on residents' demand for services, and social structural equity based on differences in group needs $[29,30]$. Resource quantity parity mainly considers indicators such as green space per capita and green space ratio [31], which does not consider the actual spatial layout of the UGS [32]. The perspective on the equity of spatial structure mainly relies on the advancement of GIS technology and the development of various scientific evaluation methods, focusing on balancing public green services with the spatial distribution of the population $[26,33]$. Social structural equity emphasizes the need to focus on equity in equal access to public green space resources across gender, race, and income groups [34,35]. Like many other developing countries in the world, China is suffering from regional development imbalances. Quite a few cities in China are experiencing unprecedented population migration and area expansion, and regional development faces severe inequalities in the local population, resident income, and well-being [36]. Among the above analytical perspectives, the spatial equity perspective enables quantitative and objective research on green space equity by integrating UGS distribution and population distribution [37], which can undoubtedly provide an efficient and consistent policy framework into urban planning and management for promoting coordinated supply in the UGS region.

Most previous quantitative studies of UGS spatial equity are based on calculating the distance or time for residents to access public green service points from their residences, often by delineating UGS buffers to quantify the accessibility of residents to green space services $[2,26,38,39]$. Many scholars have found that UGS access thresholds can significantly affect residents' access to green space benefits [5,40]. A review by Browning and Lee statistically analyzed hundreds of findings on UGS-related topics, and they found that using nested buffers with thresholds between 1000 and $1999 \mathrm{~m}$ better assessed the quantify of green vegetation people enjoy around them [41]. Based on Browning and Lee's findings, Zhang and Tan evaluated the relationship between UGS in nested buffers and people's enjoyment of the benefits of green space using the most representative sample of 1000 people across Singapore, and they found that people's physical and mental health showed the use of a nested buffer was not necessary within $400 \mathrm{~m}$ and the strongest correlation with UGS within a nested buffer with a threshold of $1600 \mathrm{~m}$ [42]. In addition, some studies incorporate the per capita UGS indicator from the regional equity perspective into the spatial equity evaluation system [43]. The German city of Berlin has set two different targets between near-residential and near-development green space, which is $6 \mathrm{~m}^{2}$ of green space per inhabitant within a near-residential area and $7 \mathrm{~m}^{2}$ per inhabitant in near-development area [44]. The Dutch government recommends that every resident should have $60 \mathrm{~m}^{2}$ of green space within a $500 \mathrm{~m}$ radius of their home [26]. Some scholars also point out that the space for the majority of people should be considered when quantifying the equity of green space use [3]. In terms of the trajectory of people's daily activities, apart from 
residential areas, people spend most of the day in places where they go to school or work, which include impermeable artificial surfaces such as office buildings, schools, factories, and shopping malls [45]. People who are permanently in these places should also have equal access to the services provided by the surrounding green spaces.

It is important to note that most UGS equity studies tend to quantify the green space services available to residents based on the number of green spaces, ignoring the variability in services provided by different types of green spaces. However, a study in Tokyo, Japan, shows that it is the type of green space rather than the amount of green space that has the most significant impact on human well-being [46]. A New York City survey comparing the relationship between trees and grass and the health status of residents showed that trees are better for physical and mental health than grass [2]. Furthermore, green space services in existing studies usually refer to a dimension of support or sociocultural services $[19,20,47]$, failing to reflect the integrated dependence of urban residents on green spaces in a comprehensive manner. Economic valuation of green space ecosystem services can quantify the benefits provided by different green spaces $[43,46-48]$. The concept of ESV per unit area has made it possible to quantify the value of ecosystem services for different land cover types [49,50]. Therefore, when evaluating the equity of urban green space based on a spatial perspective, we can differentiate different types of green space based on the ecosystem service value theory.

From the scale of research on spatial equity of UGS, most current studies are limited to specific cities in a static time perspective [35,51,52]. Few studies focus their perspectives on metropolitan areas under rapid development to analyze the equity of green space in different cities within metropolitan areas or urban agglomerations. Differences in historical policy contexts and physical geography have given rise to a range of different development types of cities and have determined these cities' green space planning policies in different contexts [53,54]. In the global context of urban expansion and transformation and upgrading, a detailed understanding of the evolution of past green spaces in different cities is necessary for a more precise formulation of urban greening policies for the future. Therefore, it is necessary to analyze the equity of people's access to UGS on a larger temporal and spatial scale [26,53]. In 2019, the Chinese government proposed to foster the development of modern metropolitan areas with the integrated infrastructure and a shared ecological environment [55]. As an important part of public infrastructure and ecological environmental protection, UGS is crucial to the coordinated development of metropolitan area regions and the enhancement of residents' well-being. In-depth analysis of the spatial and temporal variation of green space equity among different cities within the metro area and rational metropolitan area green space planning and policy recommendations based on quantitative scientific findings are essential for promoting and improving the high-quality and sustainable development of the metro region in the future.

This paper first constructs a theoretical framework for evaluating and promoting UGS equity in metro areas based on the perspective of human activities. Then we select Wuhan metropolitan area (including nine cities) in central China as an empirical study area to test the theoretical framework. Compared with the existing literature, the new contributions of this paper are as follows: first, we proposed an integrated framework to evaluate and improve the equity of UGS, which can be used by local governments to quickly and objectively evaluate UGS fairness and provide corresponding urban greening recommendations. Second, based on the ecosystem service value theory, we can quantify green space fairness by differentiating different types of green spaces and considering the value of services provided by green spaces in an integrated manner. Finally, the nested buffer algorithm we designed considers the effects of multiple distances and the spatial distribution of population activities when quantifying the Green Space Ecosystem Service Value (GSV) around residents. 


\section{Materials and Methods}

According to the research background and research objectives, a research framework was designed in this paper, including the following four steps (Figure 1): (1) reclassification and data processing of time-series land cover and population distribution products of the study area, and assigning values to different types of green space pixels based on ecosystem service value theory; (2) quantifying GSV around residents at the pixel level, considering the difference in distance from green space to artificial surfaces and the influence of population size; (3) based on the results of the buffer analysis, calculating the Gini coefficient of green space distribution at the city level, and analyzing the spatial and temporal changes of green space equity in the study area; (4) suggesting future greening policies for cities in the Wuhan metropolitan area concerning the above analysis results.

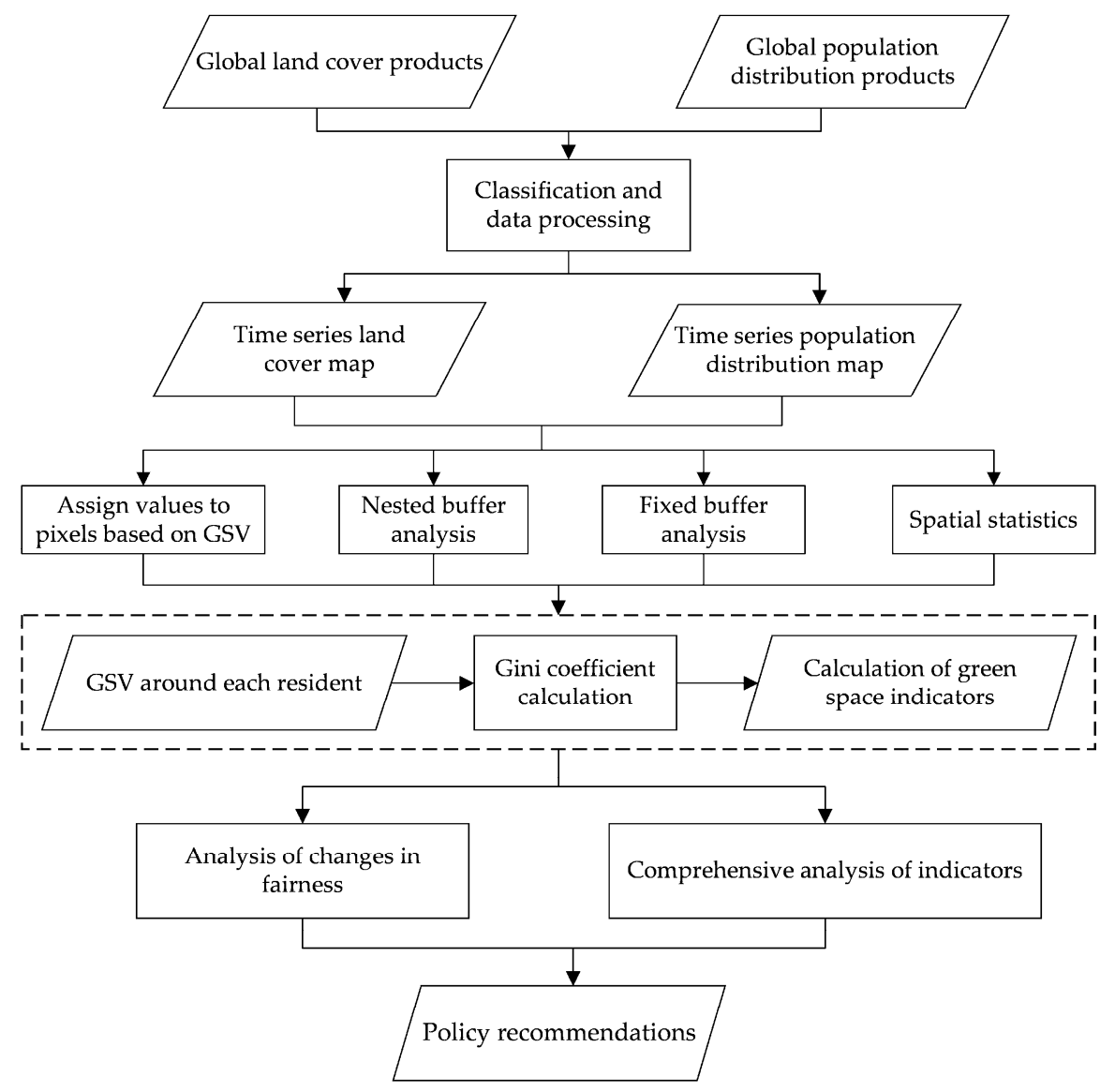

Figure 1. The research framework.

\subsection{Study Area}

The Wuhan metropolitan area is located in the middle reaches of the Yangtze and the eastern part of Hubei province $\left(28^{\circ} 50^{\prime}-31^{\circ} 57^{\prime} \mathrm{N}, 112^{\circ} 22^{\prime}-116^{\circ} 22^{\prime} \mathrm{E}\right)$, with a total area of $58,052 \mathrm{~km}^{2}$. It is the most promising and dynamic metropolitan area in central China (Figure 2). For the following reasons, this paper chooses the Wuhan metro area, the largest inland area in China, as the study area. First, previous case studies on UGS justice in China's urban agglomerations and metropolitan regions have mainly focused on those relatively developed eastern regions, such as the Yangtze river delta urban agglomeration, the Guangdong-Hong Kong-Macao greater bay area, and the Shanghai metropolitan area [3,56-58]. Therefore, typical case studies of inland metropolitan areas can help enrich the existing research results. Second, the Wuhan metro area is experiencing rapid population and economic growth recently. With a resident population of 31.87 million (55.2\% of Hubei province) and a GDP of 2.63 trillion yuan ( $60.5 \%$ of Hubei province) in 
2020, it is significant to improve environmental justice and social equity in the city by providing adequate urban green space services for a large number of residents. Finally, the development within the Wuhan metropolitan area has been uneven since its inception, with Wuhan city occupying more than one third of the metro area's GDP and population. In contrast, the eight surrounding cities lag far behind it, and the residents of the metro area have long suffered from the uneven distribution of green space resources. Therefore, achieving an equitable distribution of green space resources in the Wuhan metropolitan area has become a primary goal of the local government.

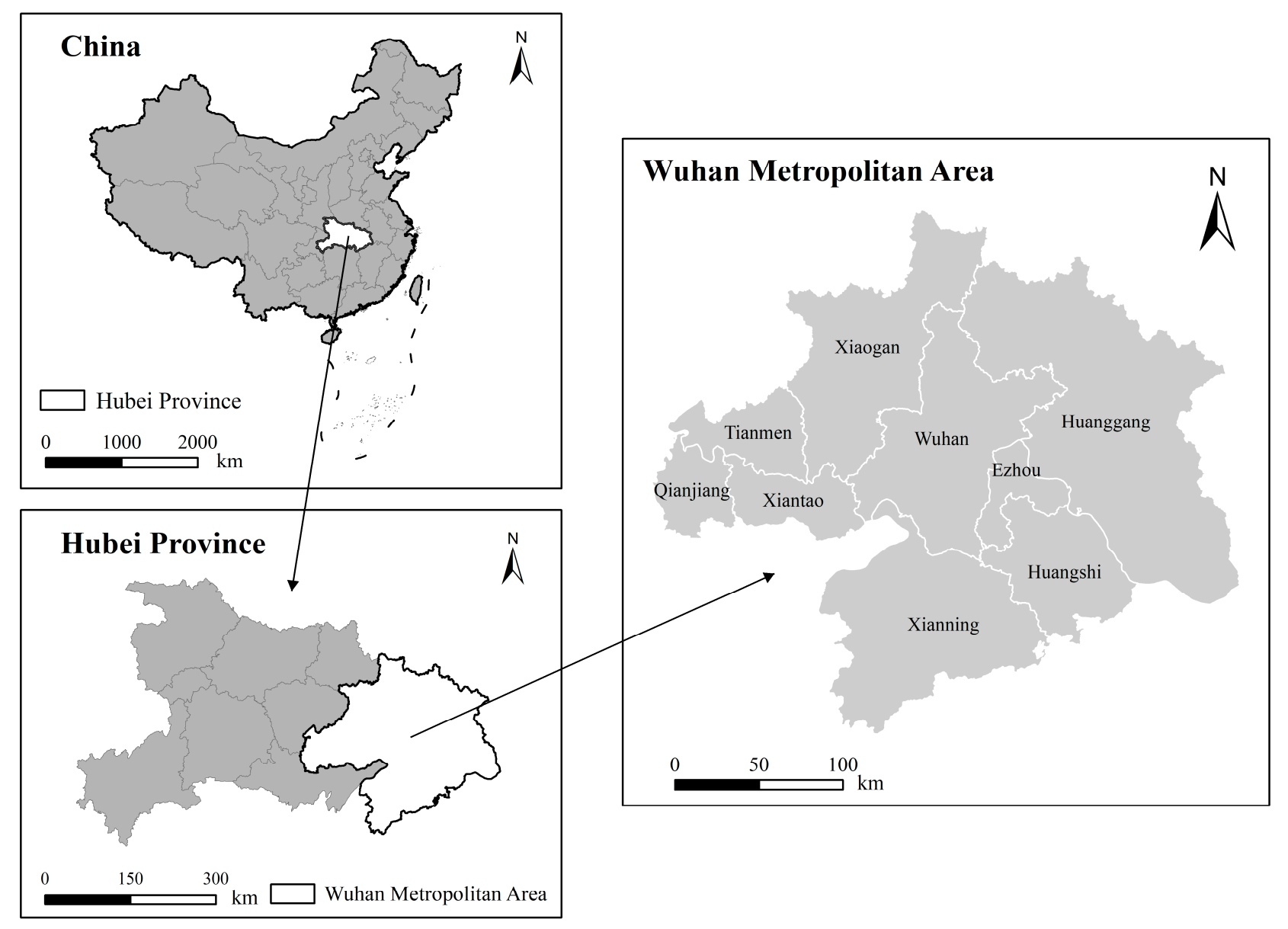

Figure 2. Location of Wuhan metropolitan area in China.

\subsection{Data Collection and Processing}

This study collected a dataset consisting of land cover data and population distribution data for the study area. The land cover data are derived from the GlobeLand30 dataset published by the Chinese Ministry of Natural Resources (http:/ / www.globallandcover.com/, accessed on 20 December 2020), which includes 10 land cover types for 2000, 2010 and 2020, namely: cultivated land, forest, grassland, shrubland, wetland (with green vegetation growth), water bodies, tundra, artificial surfaces, bare land, permanent snow and ice. Accuracy validation studies in more than a dozen countries/regions worldwide have shown that the dataset achieves an average accuracy of $80 \%$ for all three periods [59,60]. In this study, impermeable artificial surfaces were defined as human activity areas, and cultivated land, forest, grassland, shrubland, and wetland covered with green vegetation were classified as green space $[3,54]$ (Figure 3 ). In addition, we downloaded population distribution data from WorldPop (https: / / www.worldpop.org/, accessed on 22 December 2020) covering the study area for 2000, 2010, and 2020 with a spatial resolution of approximately $90 \mathrm{~m}$. 
The WorldPop project is a spatialized population layer that accurately depicts population distribution and reflects information about people's daily activities [61,62]. To match the land cover data, we resampled the spatial resolution of the Worldpop data in the study area to $30 \mathrm{~m}$.

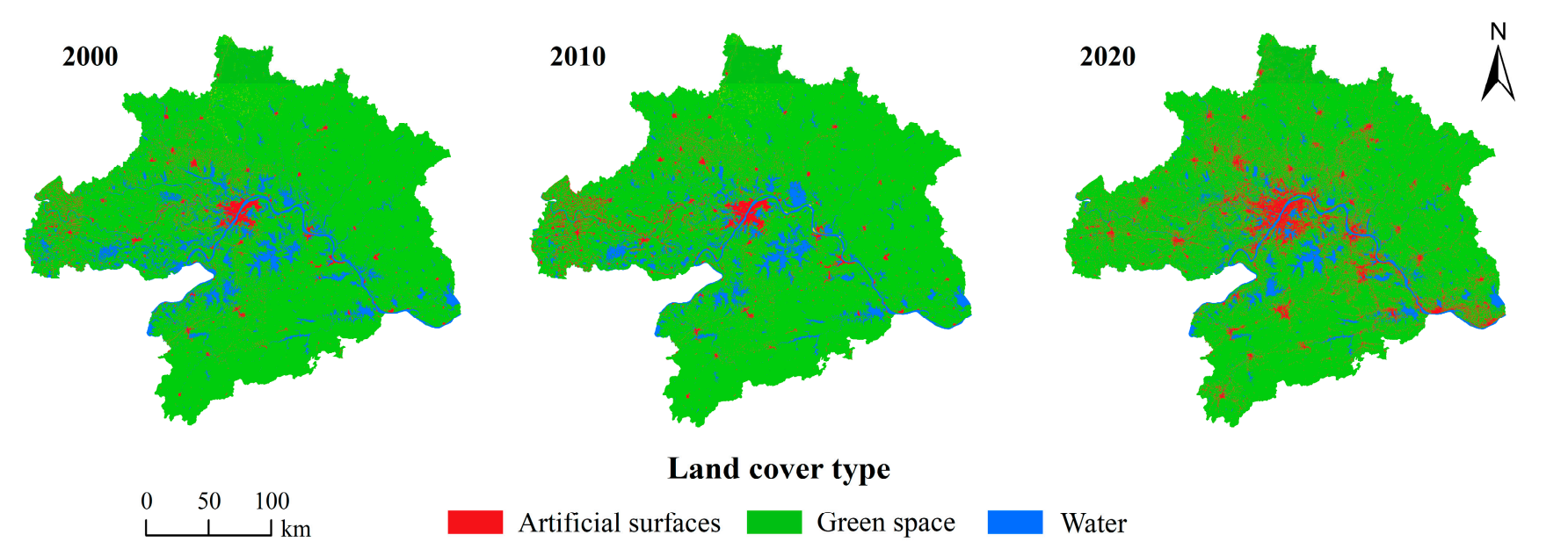

Figure 3. Land cover maps of 2000, 2010 and 2020.

\subsection{Iterative Buffer-Based Quantification of GSV Around People}

Distance and green space type are important factors limiting the use of green space, and the various services provided by green space show a decreasing trend with increasing distance in a certain spatial range. Traditional fixed buffers (circles centered on points of a certain radius) cannot objectively express the degree to which people enjoy the surrounding green space. Based on the literature review of nested buffers, a nested buffer algorithm that incorporates different green space types and their different distances from the artificial surface is designed in this study with a single artificial surface pixel as the center of the circle (Figure 4). To quantify the ecosystem services provided by different types of green spaces, we used a valuation method for terrestrial ecosystem services in China constructed by Chinese scholars Xie et al. [50]. The method lists the value of ecosystem services (including provisioning, support, cultural and social services) provided per unit area of different land cover types [50]. The specific steps are as follows: (1) based on different green space unit area ESV types, assign values to different types of green space pixels (Table 1). (2) Set the initial buffer radius of the artificial surface pixel and the radius that increases with each iteration. We set the initial radius to $400 \mathrm{~m}$ (about 13 pixels lengths) and the radius to be increased by $30 \mathrm{~m}$ (1 pixel length) for each iteration. (3) Set the number of iterations for nested buffer analysis. Let $i(i=0,1,2,3, \ldots, n)$ denote the iteration number. An iterative buffer of radius $1600 \mathrm{~m}$ is used to quantify the GSV around the artificial surface pixel, so the number of iterations $\mathrm{n}$ is set to 40 . (4) Calculate the green space pixel value $G_{i}(i=0,1$, $2,3, \ldots, 40)$ covered by each buffer, and count the green space pixel value $\sum_{0}^{40} G_{i}$ covered by all buffers. (5) Average $\sum_{0}^{40} G_{i}$ with the number of population distributions of a single artificial surface pixel and calculate the GSV available to residents.

Table 1. Pixel values of different types of green space.

\begin{tabular}{ccc}
\hline Type of UGS & Ecosystem Service Equivalent Value & Green Space Value on Pixel Level ( $\left.\frac{E S V}{3.95}\right)$ \\
\hline Cultivated land & 3.95 & 1.00 \\
Grassland and shrubland & 12.38 & 3.13 \\
Forest & 21.19 & 5.36 \\
Wetland & 52.02 & 13.17 \\
\hline
\end{tabular}




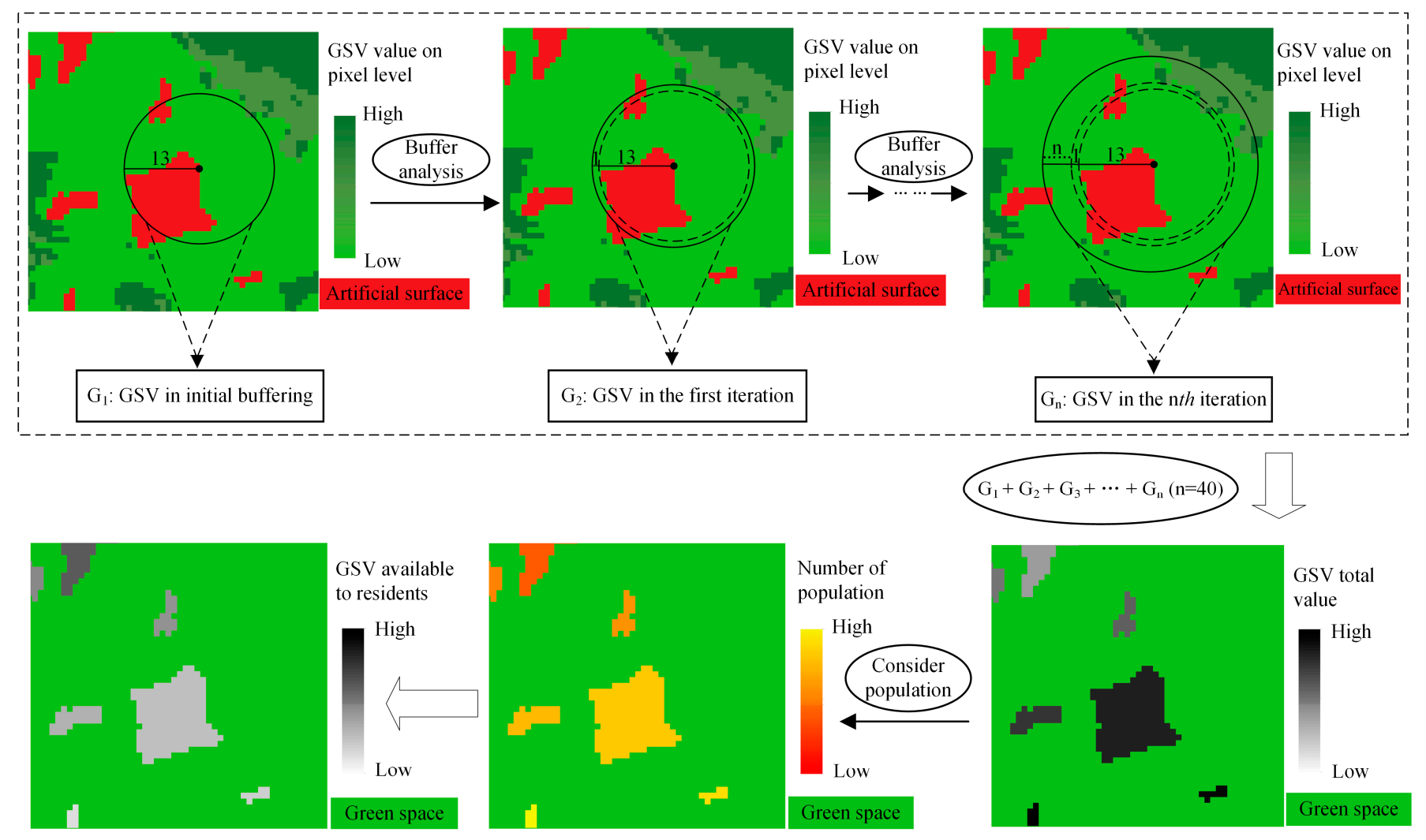

Figure 4. Quantification program of GSV available to residents.

\subsection{Gini Coefficient-Based Green Space Fairness Measurement on City Level}

The Gini coefficient is a common indicator used internationally to measure the income gap between residents of a country or region [63]. As the most widely used index of inequality, the Gini coefficient has a maximum value of 1 and a minimum value equal to 0 . The closer its value to 0 indicates that the income distribution tends to be more equal [64]. The Gini coefficient was initially used in economics as a measure of the fairness of economic income distribution. In recent years, the Gini coefficient has also been gradually applied to evaluate the equity of spatial distribution of education [65], health [66], and biodiversity [67]. Based on the statistical results of GSV around residents, we used the Gini coefficient to measure the equity of green space distribution among cities in the Wuhan metropolitan area. The Gini coefficient $G_{c i t y}$ is calculated according to the following formula [68].

$$
G_{c i t y}=1+\frac{1}{q}-\left(\frac{2}{\bar{P} \cdot q^{2}}\right) \sum_{j=1}^{q}\left[(q-j+1) \cdot P_{j}\right]
$$

where $G_{c i t y}$ represents the inequity of green space distribution within the city, $q$ is the number of artificial surface pixels within the administrative boundary of the city, $P_{j}$ represents the GSV around the inhabitants of the $j$ th artificial surface pixel, and $\bar{P}$ is the average of the GSV around the inhabitants within the city.

\subsection{Green Space Optimization Measurement on City Level}

Cities with higher green space equity do not necessarily mean that they can provide sufficient green space for their residents. In order to provide objective and different greening policy recommendations for each city, this study further constructs two objective and rigorous indicators $E_{\text {city }}$ and $T_{\text {city }}$ based on Sections 2.3 and 2.4. $E_{\text {city }}$ consists of two parameters within a single city. The first type of parameter is the mean $\bar{P}$ of GSV around 
inner-city residents based on nested buffers derived in this study, which we define as GSV provision in a single city. The second type of parameter is the mean value $\bar{F}$ of GSV around inner-city residents quantified based on a fixed buffer of $1600 \mathrm{~m}$ radius. The ratio $E_{\text {city }}$ of the two types of parameters can quantify the optimization effect of the current green space layout within the city. In addition, for cities where the green space provision is significantly lower than the metropolitan area average, the greening policy focuses on optimizing the layout of existing green space and increasing the amount of green space adjacent to people's activity areas. Most cities currently implement optimization of green space layout by planting trees and grasses [14]. Given the large differences in ecosystem service values of different green spaces, we further construct a green space optimization path indicator $T_{\text {city }}$ based on the nested buffer algorithm in Section 2.3. This optimization path indicator can help those cities with low GSV provision identify the types of green spaces that need to be increased as a priority. The calculations of $T_{\text {city }}$ is shown in Formula (3). $L_{c i t y}$ is the mean value of GSV supply provided by forest within a single city, $C_{\text {city }}$ is the mean value of GSV supply provided by grassland and shrubland within a single city, and $S_{\text {city }}$ is the mean value of GSV supply provided by wetland within a single city.

$$
\begin{gathered}
E_{c i t y}=\frac{\bar{P}}{\bar{F}} \\
T_{c i t y}=\operatorname{Min}\left(L_{c i t y}, C_{c i t y}, S_{c i t y}\right)
\end{gathered}
$$

\section{Results and Analysis}

\subsection{Disparities in GSV Provision on City Level}

We calculated the results of GSV distribution in Wuhan metropolitan area for three periods according to the method in Section 2.3 (Figure 5), and the pixel value represents the GSV around each resident. Based on these results, we further analyzed the distribution of GSV supply and its degree of variation among the nine cities in the metropolitan area. The histogram of GSV supply on city level from 2000 to 2020 is given in Figure 6. The results showed that there were large temporal and spatial differences in GSV provision among cities in the Wuhan metropolitan area. The supply of GSV in most cities was significantly lower in 2010 than in the other two years. Except for Tianmen and Xianning, the supply of GSV in other cities showed a trend of "decreasing and then increasing" in the past 20 years. As a whole, the total GSV provision in Wuhan metropolitan area is ranked by year: $2010<2000<2020$, and the GSV provision in Xianning, located at the southern end of the metropolitan area, has been leading in the three periods, while the GSV supply in Wuhan, the central city, has been at the middle level in all three periods.
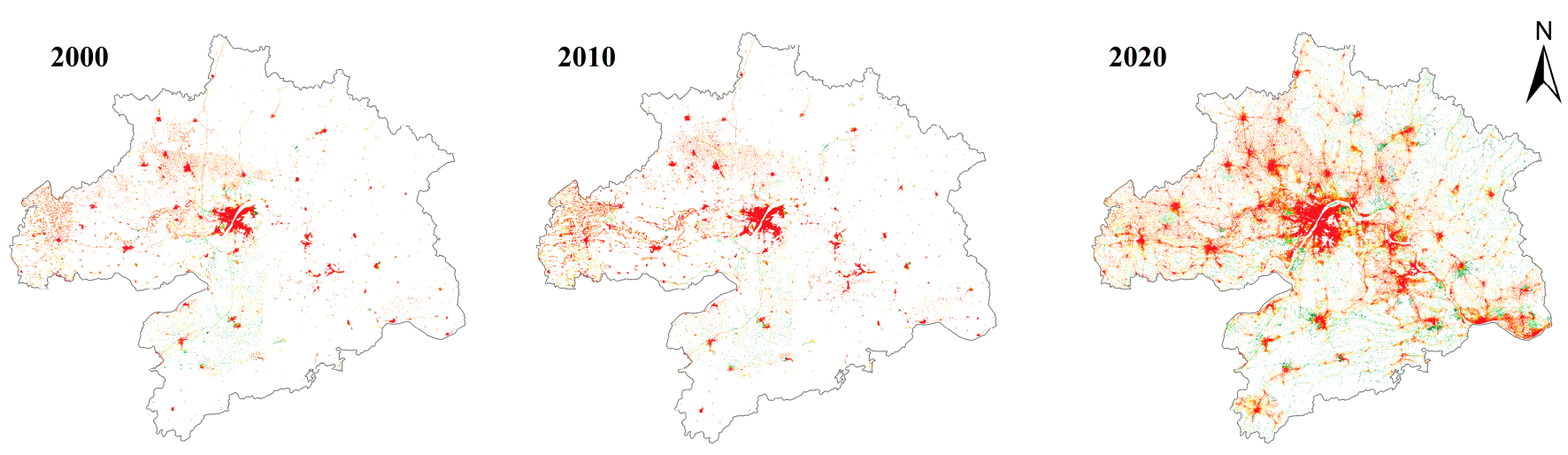

GSV around each resident on pixel level $\left(\times 10^{3}\right)$
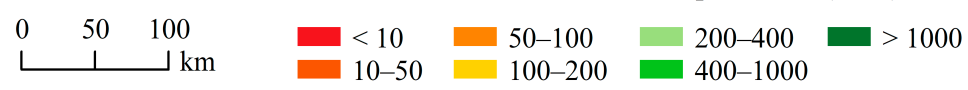

Figure 5. Distribution of the GSV available to residents. 


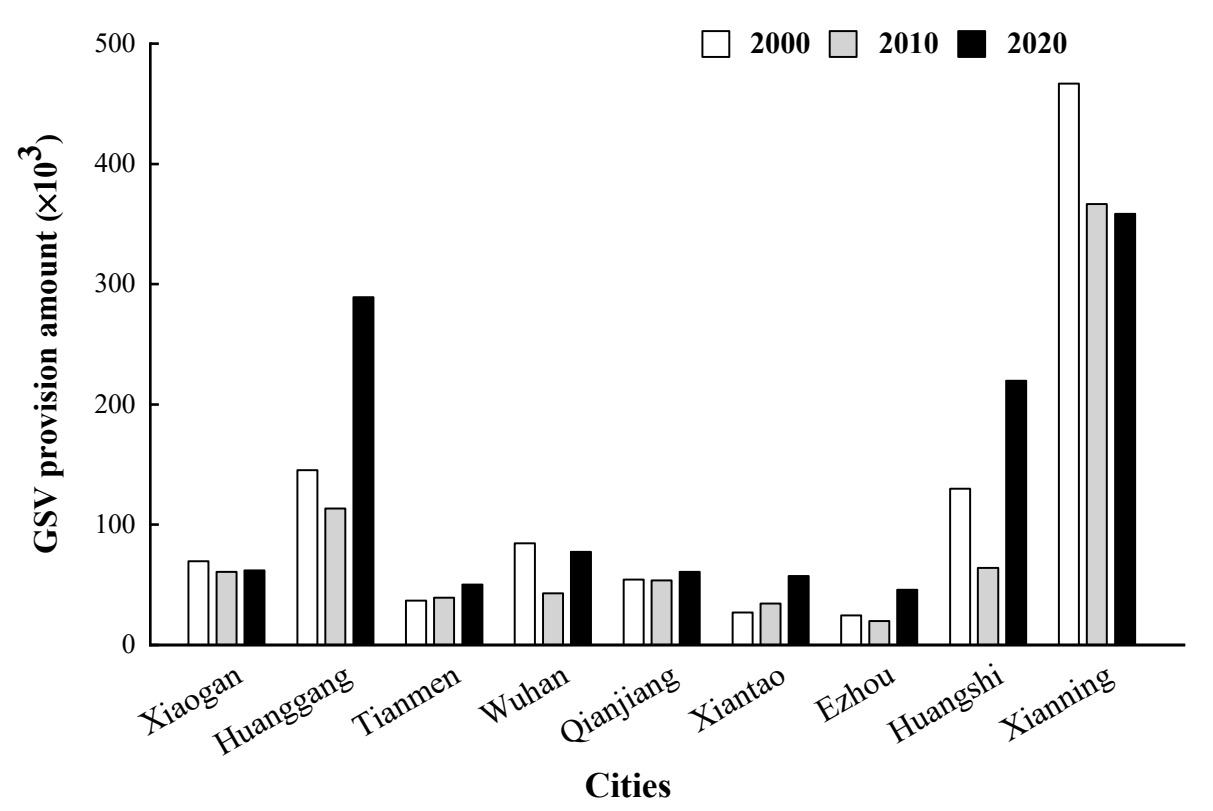

Figure 6. GSV provision on city level of 2000, 2010 and 2020.

\subsection{Temporal and Spatial Changes of Green Space Fairness on City Level}

We plotted the $G_{\text {city }}$ spatial distribution of cities in the Wuhan metropolitan area in 2000, 2010 and 2020 based on the calculation results (Figure 7). Although the total GSV supply in the Wuhan metro area peaked in 2020, the $G_{\text {city }}$ of most cities did not decrease in this year, but increased slightly. Figure 8 shows the city-level $G_{c i t y}$ histogram from 2000 to 2020. Overall, the $G_{c i t y}$ maximum value appears in Wuhan in 2020, indicating that its urban green space equity is the worst among all cities in the last three periods, while the minimum value appears in Tianmen in 2000, indicating that its equity is optimal. From 2000 to 2020, the Gini coefficients of Tianmen, Wuhan and Qianjiang, increased year by year, indicating a decreasing trend of fairness in these cities, and only three cities (Xiaogan, Huanggang and Ezhou) showed an improving trend of green space fairness (Gini coefficient decreased year by year).
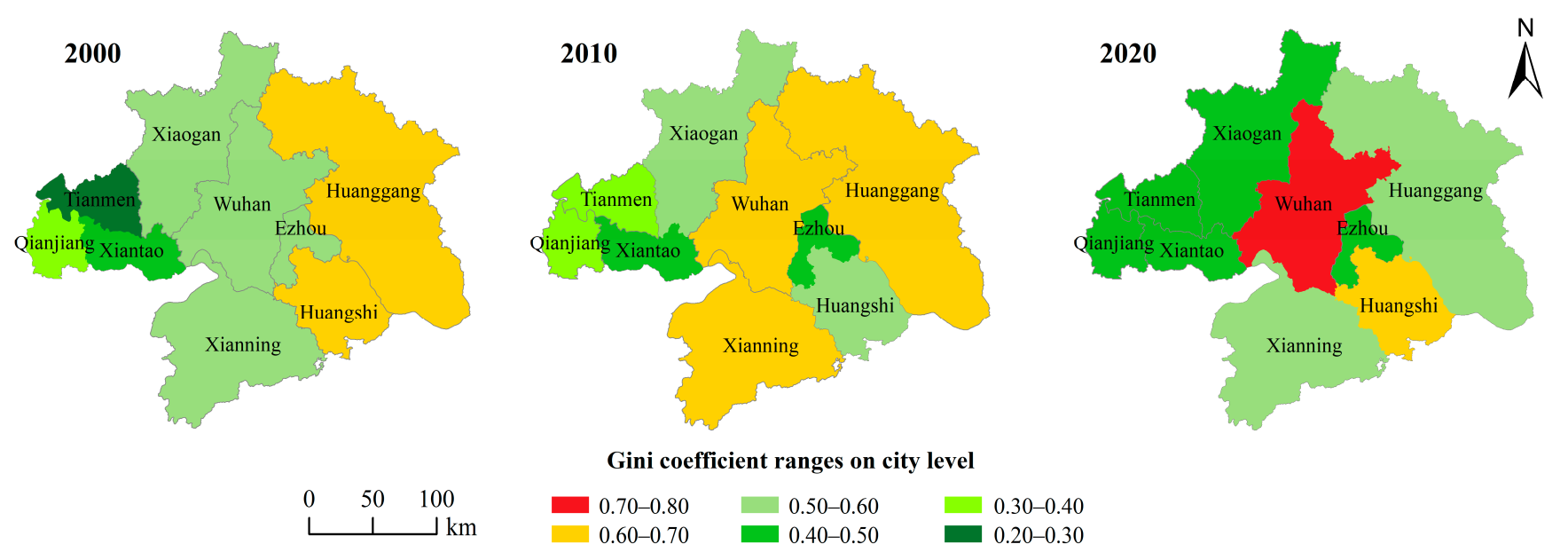

Gini coefficient ranges on city level

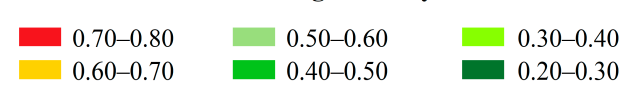

Figure 7. Gini coefficient ranges on city level. 


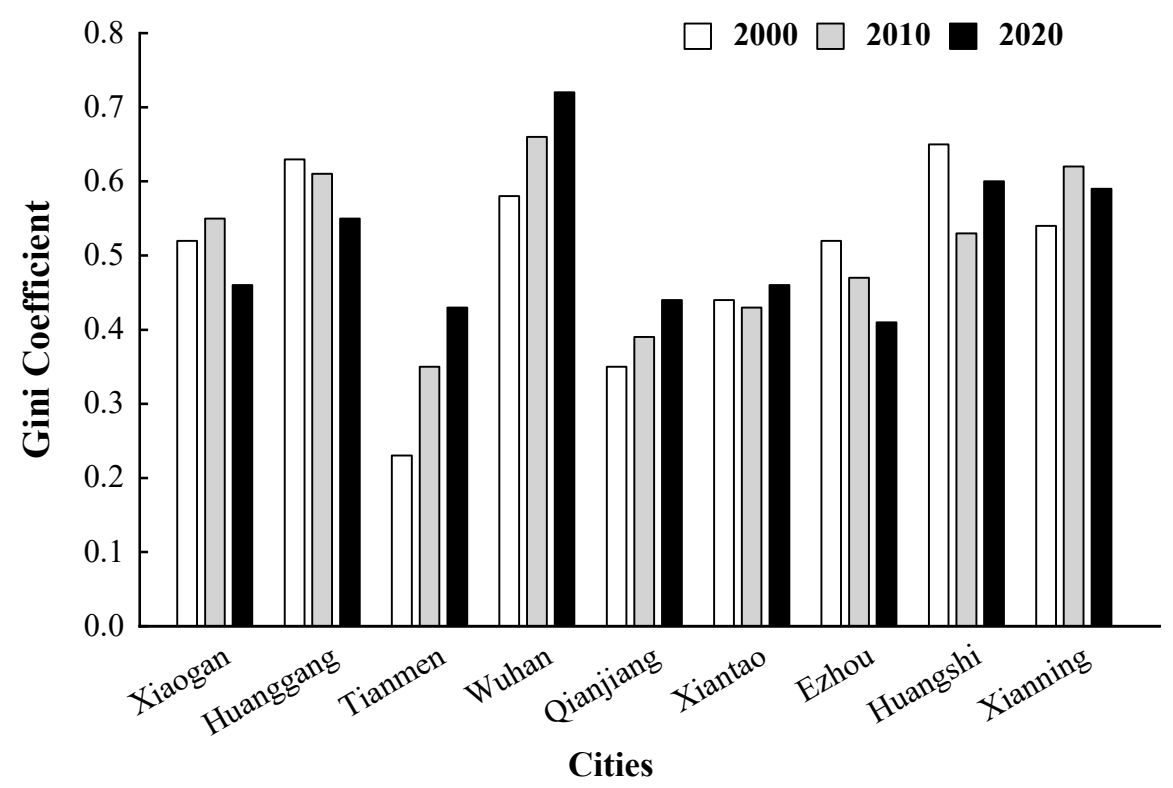

Figure 8. Histogram of the Gini coefficient on city level.

\subsection{Green Space Policy Recommendations for Different Cities}

Based on the results of the GSV supply and equity indicators at the city level, this study analyzed and compared the $E_{c i t y}$ and $T_{\text {city }}$ indicator values of each city to identify the current problems in the distribution of green space in each city and to develop strategies for future green space planning (Table 2). For example, Huanggang and Xianning, which have high GSV provision but low equity and poor green space layout optimization, should tilt their future green space resources toward areas with low GSV values for residents. On the other hand, for cities with better green space equity and layout optimization but GSV provision far behind the metropolitan area average, such as Tianmen and Qianjiang, these cities should gradually expand tree planting and wetland development in the future without changing the current green space layout.

Table 2. Statistical indicators and future policy recommendations for different cities.

\begin{tabular}{|c|c|c|c|c|c|}
\hline Cities & $\begin{array}{l}\text { GSV Provision } \\
\text { for } 2020\left(\times 10^{3}\right)\end{array}$ & $G_{c i t y}$ for 2020 & $E_{\text {city }}$ for 2020 & $T_{\text {city }}$ for 2020 & Policy Recommendations \\
\hline Average value & 135.68 & 0.52 & 10.71 & - & - \\
\hline Xiaogan & 62.00 & 0.46 & 9.19 & $C_{\text {city }}$ & $\begin{array}{l}\text { Increase GSV and optimization } \\
\text { and plant grass and bush }\end{array}$ \\
\hline Huanggang & 289.21 & 0.55 & 6.93 & - & $\begin{array}{l}\text { Improve fairness and } \\
\text { optimization }\end{array}$ \\
\hline Tianmen & 50.31 & 0.43 & 14.52 & $L_{\text {city }}$ & $\begin{array}{l}\text { Increase GSV and plant trees } \\
\text { Increase GSV and Improve }\end{array}$ \\
\hline Wuhan & 77.44 & 0.72 & 8.92 & $C_{\text {city }}$ & $\begin{array}{l}\text { fairness and optimization and } \\
\text { plant grass and bush }\end{array}$ \\
\hline Qianjiang & 60.93 & 0.44 & 14.57 & $S_{\text {city }}$ & $\begin{array}{l}\text { Increase GSV and increase } \\
\text { wetland }\end{array}$ \\
\hline Xiantao & 57.33 & 0.46 & 13.95 & $L_{\text {city }}$ & Increase GSV and plant trees \\
\hline Ezhou & 45.85 & 0.41 & 12.64 & $C_{\text {city }}$ & $\begin{array}{l}\text { Increase GSV and plant grass } \\
\text { and bush }\end{array}$ \\
\hline Huangshi & 219.52 & 0.60 & 8.80 & - & $\begin{array}{l}\text { Improve fairness and } \\
\text { optimization }\end{array}$ \\
\hline Xianning & 358.51 & 0.59 & 6.86 & - & $\begin{array}{l}\text { Improve fairness and } \\
\text { optimization }\end{array}$ \\
\hline
\end{tabular}




\section{Discussion}

\subsection{Quantification of UGS from a ESV Perspective}

In general, the services provided by different types of green spaces to humans vary significantly. People often perceive and evaluate green spaces based on the services provided by different UGS; for example, some studies have found that the frequency with which people visit open spaces varies with the type of green space and landscape characteristics $[48,69]$. However, most existing studies evaluated the equity of green spaces singly from the perspective of the UGS area $[3,26]$ or the view of support or sociocultural services [46,47]. Those studies could hardly reflect the dependency of urban systems on UGS in a true and multidimensional way. The multiple services provided by UGS, such as support, provisioning, and sociocultural services, fall under the category of ecosystem services. The monetary quantification of ecosystem services has been fruitful in recent years. Therefore, to make the research results more objective and rigorous, we applied the value of ecosystem services to quantify the services provided by different types of green spaces.

\subsection{Comparison in Fairness under Demographic Factors}

Previous research on the UGS fairness has centered on a socioeconomic perspective $[35,70]$. However, as one of the important influencing factors affecting green space equity, few studies have spatially considered the impact of population size on green space fairness. Even fewer quantitative studies on green space fairness are based on fine-grained data on spatial population distribution. Existing studies spatially treat artificial surface pixels as human activity areas and treat different types of artificial surfaces (e.g., factories, schools, residential areas) equally [3]. However, the reality is quite different, where human activity areas with lower population numbers undoubtedly enjoy more green space services in a similar green space layout scenario. Here, we remove the population factor to obtain the corresponding findings and then compare and analyze the differences in green space equity between cities in 2020 under the two scenarios (Figure 9). The results show that the differences in green space equity between the two scenarios are significant. After disregarding the population factor, the Gini coefficients of most cities in the Wuhan metropolitan area experienced a certain increase and were mostly concentrated in the range of 0.50 to 0.70 .
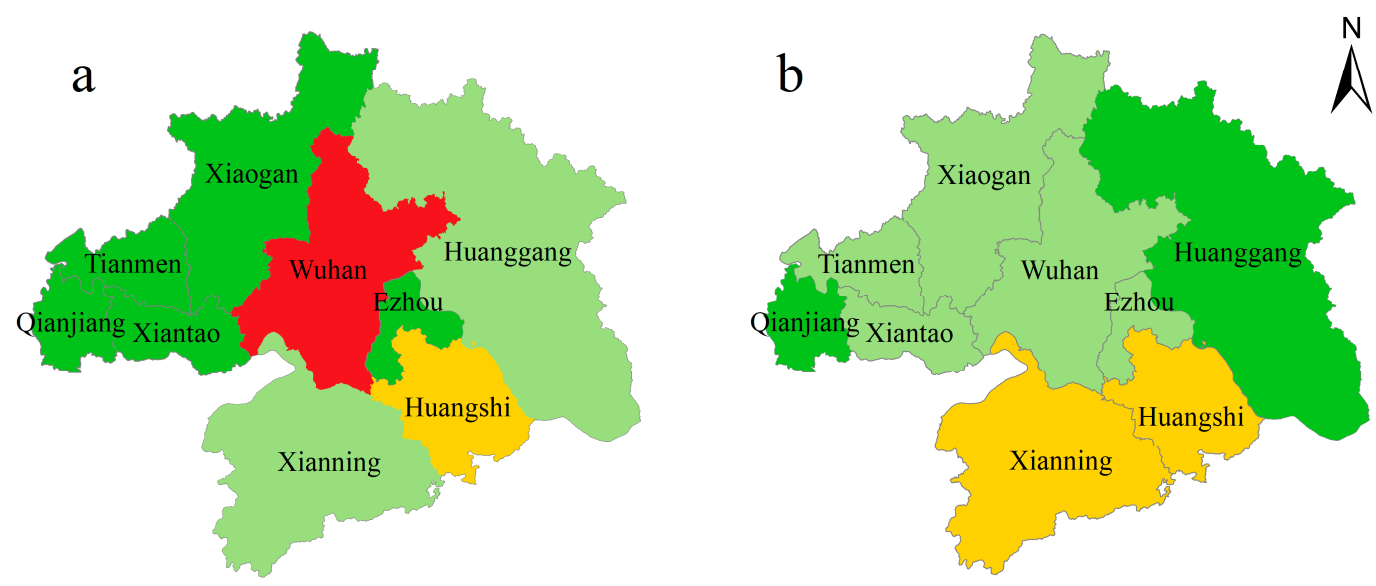

Gini coefficient ranges on city level

$\begin{array}{cccrrr}0 & 50 & 100 & 0.70-0.80 & 0.50-0.60 & 0.30-0.40 \\ \mathrm{~L} & \mathrm{l} & \mathrm{km} & 0.60-0.70 & 0.40-0.50 & 0.20-0.30\end{array}$

Figure 9. Gini coefficient on city level based on both methods: (a) results of this study; (b) results of not considering the population factor. 


\subsection{Differences in Research Perspectives between China and Developed Countries}

Most previous studies on UGS equity have focused on more urbanized countries [26,71] and wealthy cities [53,72] in North America and Europe. These UGS equity studies focus on the rights of low-income and minority groups to access UGS services and highlight public participation mechanisms in their recommendations for improving UGS equity [36,39,52]. However, studies on UGS equity in those less urbanized and economically underdeveloped areas are still relatively lacking. Unlike some developed cities in Europe and the United States, specific factors such as natural endowments, land policies, and significant strategic development plans influence UGS equity in China's regional development process [73]. China is a developing country with a vast territory and a large population. Its central and eastern cities are in a rapid growth phase, and these rapidly urbanizing regions are currently facing severe UGS imbalances. The Chinese government has been taking policy measures to alleviate such inequities [36]. Thus, the research perspective of UGS equity in this paper is based on the latest national strategic planning of metropolitan area integration construction and regional balanced development. This paper focuses on some top-down policy recommendations to improve the current situation of inequitable UGS in the Wuhan metro area and achieve balanced regional development in the Wuhan metro area based on the position of local governments. This paper's research methods and findings could be a reference for promoting regional integration and formulating UGS equity policies in other metropolitan areas in China and research on UGS equity in other developing countries and regions with uneven regional development. It is worth noting that the relevant policy research of UGS should further draw on the useful results of bottom-up and public participation in Europe and the United States, and other countries.

\subsection{Contributions and Limitations of this Study}

The scarcity of UGS can lead to inadequate ecosystem services, which in turn affects the well-being of residents. As the largest developing country, the central government of China has proposed a series of strategic goals for sustainable and coordinated urban development, involving the construction of ecologically civilized cities, green cities, and sponge cities. However, due to the core orientation of economic development by various local governments in the past and the lack of effective monitoring mechanisms, the effects received by these policies are usually limited. Central China has long suffered from the dilemma that economic development and equitable resource distribution play against each other. For example, as the core economic zone of the metro area in central China, Wuhan brings together many population and industrial resources from neighboring cities. Yet, its uneven construction of public infrastructure services has seriously lagged behind the city's development. In the context of China's current efforts to establish a number of inclusive cities that attract global talent and investment by formulating the territorial space planning for different administrative levels of the country, it is crucial to use territorial space planning to strengthen the control of urban green space planning and thus improve the UGS fairness. In February 2021, the Ministry of Natural Resources of China officially released the draft of the "Regulations for the preparation of territorial spatial planning in metropolitan areas" for public consultation, which focuses on promoting the common construction and sharing of regional infrastructure [74]. Therefore, it is important to study the spatial and temporal changes of green space equity in the Wuhan metropolitan area in the past 20 years, especially to propose corresponding policy recommendations for different cities to improve the equity of green space allocation.

This study attempted to construct a simple and easy-to-use theoretical framework to evaluate the level of UGS fairness and its improvement measures at the city level, using long-time series remote sensing images from a rich source and easily accessible database. Therefore, this study will benefit those developing countries and regions undergoing unbalanced UGS development and urgently need to promote the equitable sharing of UGS in a quick and easy way. 
However, there is still a certain degree of deficiency in this paper. Due to the limitation of the spatial resolution of the long-time remote sensing impact obtained for free, the land cover data we got did not take into account the UGS less than $900 \mathrm{~m}^{2}$ in size. Therefore, some small and micro-sized parks, including community parks, private gardens, and roadside green belts, may be excluded from our study, which will undoubtedly lead to some bias in our findings. To overcome this limitation, we will combine higher precision multisource data for coverage analysis to consider small parks and green belts in future studies.

\section{Conclusions}

This study quantifies the changes of green space equity in Wuhan metropolitan area from 2000 to 2020 based on long time series land cover data and population spatial distribution data. The results show that there are significant differences in fairness among different cities, and the fairness of the same city shows large ups and downs in the last 20 years, and most of the cities have not achieved better results in guaranteeing residents ${ }^{\prime}$ access to adequate amount of UGS services and improving fairness while developing at a high rate. We further suggest future UGS planning for each city based on the current status of each city's green space. This study has some theoretical value for public infrastructure planning in metropolitan areas and urban agglomerations, and future research work should consider numerous small and micro-sized green spaces. In addition, since metropolitan areas are an important part of the formation and development of urban agglomerations, the next relevant research can be considered within the context of urban agglomerations. With the current open-source and free multisource global land cover and population spatial distribution products, we can successfully achieve this goal.

Author Contributions: Conceptualization, P.C. and M.M.; writing-original draft preparation, P.C. and M.M.; writing-review and editing, M.M., W.H. and A.Z.; supervision, W.H. and A.Z. All authors have read and agreed to the published version of the manuscript.

Funding: This research was funded by the National Natural Science Foundation of China (Program No. 71873053), the Major Projects of the National Social Science Fund (Program No. 18ZDA054), and the Fundamental Research Funds for the Central Universities (Program No. 2662019FW017).

Institutional Review Board Statement: Not applicable.

Data Availability Statement: Not applicable.

Acknowledgments: The authors would like to thank the Ministry of Natural Resources of China and WorldPop for making their datasets freely available.

Conflicts of Interest: The authors declare no conflict of interest.

\section{References}

1. Seto, K.C.; Fragkias, M.; Güneralp, B.; Reilly, M.K. A Meta-Analysis of Global Urban Land Expansion. PLoS ONE 2011, 6, e23777. [CrossRef]

2. Reid, C.E.; Clougherty, J.E.; Shmool, J.L.C.; Kubzansky, L.D. Is All Urban Green Space the Same? A Comparison of the Health Benefits of Trees and Grass in New York City. Int. J. Environ. Res. Public Health 2017, 14, 1411. [CrossRef]

3. Yang, G.; Zhao, Y.; Xing, H.; Fu, Y.; Liu, G.; Kang, X.; Mai, X. Understanding the changes in spatial fairness of urban greenery using time-series remote sensing images: A case study of Guangdong-Hong Kong-Macao Greater Bay. Sci. Total Environ. 2020, 715, 136763. [CrossRef]

4. Maas, J.; Verheij, R.A.; Groenewegen, P.P.; de Vries, S.; Spreeuwenberg, P. Green space, urbanity, and health: How strong is the relation? J. Epidemiol. Community Health 2006, 60, 587-592. [CrossRef]

5. De Vries, S.; Verheij, R.A.; Groenewegen, P.P.; Spreeuwenberg, P. Natural Environments—Healthy Environments? An Exploratory Analysis of the Relationship between Greenspace and Health. Environ. Plan. A 2003, 35, 1717-1731. [CrossRef]

6. Fuller, R.A.; Gaston, K.J. The scaling of green space coverage in European cities. Biol. Lett. 2009, 5, 352-355. [CrossRef]

7. Millennium Ecosystem Assessment. Ecosystems and Human Well-Being; Island Press: Washington, DC, USA, 2005 ; Volume 5.

8. Nesbitt, L.; Meitner, M.J.; Sheppard, S.R.J.; Girling, C. The dimensions of urban green equity: A framework for analysis. Urban For. Urban Green. 2018, 34, 240-248. [CrossRef]

9. Bowler, D.E.; Buyung-Ali, L.; Knight, T.M.; Pullin, A.S. Urban greening to cool towns and cities: A systematic review of the empirical evidence. Landsc. Urban Plan. 2010, 97, 147-155. [CrossRef] 
10. Pataki, D.E.; Carreiro, M.M.; Cherrier, J.; Grulke, N.E.; Jennings, V.; Pincetl, S.; Pouyat, R.V.; Whitlow, T.H.; Zipperer, W.C. Coupling biogeochemical cycles in urban environments: Ecosystem services, green solutions, and misconceptions. Front. Ecol. Environ. 2011, 9, 27-36. [CrossRef]

11. Fang, C.-F.; Ling, D.-L. Investigation of the noise reduction provided by tree belts. Landsc. Urban Plan. 2003, 63, 187-195. [CrossRef]

12. Margaritis, E.; Kang, J. Relationship between green space-related morphology and noise pollution. Ecol. Indic. 2017, 72, 921-933. [CrossRef]

13. Akbari, H. Shade trees reduce building energy use and CO2 emissions from power plants. Environ. Pollut. 2002, 116, S119-S126. [CrossRef]

14. Kroeger, T.; Escobedo, F.J.; Hernandez, J.L.; Varela, S.; Delphin, S.; Fisher, J.R.B.; Waldron, J. Reforestation as a novel abatement and compliance measure for ground-level ozone. Proc. Natl. Acad. Sci. USA 2014, 111, E4204-E4213. [CrossRef]

15. Nowak, D.J.; Crane, D.E.; Stevens, J.C. Air pollution removal by urban trees and shrubs in the United States. Urban For. Urban Green. 2006, 4, 115-123. [CrossRef]

16. Carpenter, S.R.; Caraco, N.F.; Correll, D.L.; Howarth, R.W.; Sharpley, A.N.; Smith, V.H. Nonpoint Pollution of Surface Waters with Phosphorus and Nitrogen. Ecol. Appl. 1998, 8, 559-568. [CrossRef]

17. Roy, J.W.; Parkin, G.W.; Wagner-Riddle, C. Water Flow in Unsaturated Soil Below Turfgrass Observations and LEACHM (within EXPRES) Predictions. Soil Sci. Soc. Am. J. 2000, 64, 86-93. [CrossRef]

18. Zhang, B.; Xie, G.; Zhang, C.; Zhang, J. The economic benefits of rainwater-runoff reduction by urban green spaces: A case study in Beijing, China. J. Environ. Manag. 2012, 100, 65-71. [CrossRef]

19. Barthel, S.; Parker, J.; Ernstson, H. Food and Green Space in Cities: A Resilience Lens on Gardens and Urban Environmental Movements. Urban Stud. 2015, 52, 1321-1338. [CrossRef]

20. Cetin, M. The effect of urban planning on urban formations determining bioclimatic comfort area's effect using satellitia imagines on air quality: A case study of Bursa city. Air Qual. Atmos. Health 2019, 12, 1237-1249. [CrossRef]

21. Mitchell, R.; Popham, F. Greenspace, urbanity and health: Relationships in England. J. Epidemiol. Community Health 2007, 61, 681-683. [CrossRef] [PubMed]

22. Wolch, J.R.; Byrne, J.; Newell, J.P. Urban green space, public health, and environmental justice: The challenge of making cities 'just green enough'. Landsc. Urban Plan. 2014, 125, 234-244. [CrossRef]

23. de Vries, S.; van Dillen, S.M.E.; Groenewegen, P.P.; Spreeuwenberg, P. Streetscape greenery and health: Stress, social cohesion and physical activity as mediators. Soc. Sci. Med. 2013, 94, 26-33. [CrossRef] [PubMed]

24. Bogar, S.; Beyer, K.M. Green Space, Violence, and Crime: A Systematic Review. Trauma Violence Abuse 2016, 17, 160-171. [CrossRef]

25. Krekel, C.; Kolbe, J.; Wüstemann, H. The greener, the happier? The effect of urban land use on residential well-being. Ecol. Econ. 2016, 121, 117-127. [CrossRef]

26. Wüstemann, H.; Kalisch, D.; Kolbe, J. Access to urban green space and environmental inequalities in Germany. Landsc. Urban Plan. 2017, 164, 124-131. [CrossRef]

27. Weng, Q.H. Land use change analysis in the Zhujiang Delta of China using satellite remote sensing, GIS and stochastic modelling. J. Environ. Manag. 2002, 64, 273-284. [CrossRef]

28. Gong, P.; Liang, S.; Carlton, E.J.; Jiang, Q.; Wu, J.; Wang, L.; Remais, J.V. Urbanisation and health in China. Lancet 2012, 379, 843-852. [CrossRef]

29. Almohamad, H.; Knaack, A.L.; Habib, B.M. Assessing Spatial Equity and Accessibility of Public Green Spaces in Aleppo City, Syria. Forests 2018, 9, 706. [CrossRef]

30. Feng, S.; Chen, L.; Sun, R.; Feng, Z.; Li, J.; Khan, M.S.; Jing, Y. The Distribution and Accessibility of Urban Parks in Beijing, China: Implications of Social Equity. Int. J. Environ. Res. Public Health 2019, 16, 4894. [CrossRef]

31. Apan, A.A.; Raine, S.R.; Paterson, M.S. Mapping and analysis of changes in the riparian landscape structure of the Lockyer Valley catchment, Queensland, Australia. Landsc. Urban Plan. 2002, 59, 43-57. [CrossRef]

32. Ma, F. Spatial equity analysis of urban green space based on spatial design network analysis (sDNA): A case study of central Jinan, China. Sustain. Cities Soc. 2020, 60, 102256. [CrossRef]

33. Wu, J.; Chen, H.; Wang, H.; He, Q.; Zhou, K. Will the opening community policy improve the equity of green accessibility and in what ways?-Response based on a 2-step floating catchment area method and genetic algorithm. J. Clean. Prod. 2020, 263, 121454. [CrossRef]

34. Ernstson, H. The social production of ecosystem services: A framework for studying environmental justice and ecological complexity in urbanized landscapes. Landsc. Urban Plan. 2013, 109, 7-17. [CrossRef]

35. Kabisch, N.; Haase, D. Green justice or just green? Provision of urban green spaces in Berlin, Germany. Landsc. Urban Plan. 2014, 122, 129-139. [CrossRef]

36. Li, X.; Ma, X.; Hu, Z.; Li, S. Investigation of urban green space equity at the city level and relevant strategies for improving the provisioning in China. Land Use Policy 2021, 101, 105144. [CrossRef]

37. Xing, L.; Liu, Y.; Liu, X. Measuring spatial disparity in accessibility with a multi-mode method based on park green spaces classification in Wuhan, China. Appl. Geogr. 2018, 94, 251-261. [CrossRef]

38. Comber, A.; Brunsdon, C.; Green, E. Using a GIS-based network analysis to determine urban greenspace accessibility for different ethnic and religious groups. Landsc. Urban Plan. 2008, 86, 103-114. [CrossRef] 
39. Dai, D. Racial/ethnic and socioeconomic disparities in urban green space accessibility: Where to intervene? Landsc. Urban Plan. 2011, 102, 234-244. [CrossRef]

40. van den Berg, A.E.; Maas, J.; Verheij, R.A.; Groenewegen, P.P. Green space as a buffer between stressful life events and health. Soc. Sci. Med. 2010, 70, 1203-1210. [CrossRef]

41. Browning, M.; Lee, K. Within What Distance Does "Greenness" Best Predict Physical Health? A Systematic Review of Articles with GIS Buffer Analyses across the Lifespan. Int. J. Environ. Res. Public Health 2017, 14, 675. [CrossRef]

42. Zhang, L.; Tan, P.Y. Associations between Urban Green Spaces and Health are Dependent on the Analytical Scale and How Urban Green Spaces are Measured. Int. J. Environ. Res. Public Health 2019, 16, 578. [CrossRef]

43. Larondelle, N.; Haase, D. Urban ecosystem services assessment along a rural-urban gradient: A cross-analysis of European cities. Ecol. Indic. 2013, 29, 179-190. [CrossRef]

44. Senate Department for Urban Development and the Environment-Berlin. Availability of Public, Near Residential Green Space. Available online: https:/ / www.berlin.de/umweltatlas/en/land-use/public-green-spaces/2016/introduction/ (accessed on 12 March 2021).

45. Bastons, M.; Armengou, J. Human Habitat, Space and Place. J. Agric. Environ. Ethics 2016, 29, 559-570. [CrossRef]

46. Tsurumi, T.; Imauji, A.; Managi, S. Greenery and Subjective Well-being: Assessing the Monetary Value of Greenery by Type. Ecol. Econ. 2018, 148, 152-169. [CrossRef]

47. Panduro, T.E.; Veie, K.L. Classification and valuation of urban green spaces-A hedonic house price valuation. Landsc. Urban Plan. 2013, 120, 119-128. [CrossRef]

48. Schipperijn, J.; Ekholm, O.; Stigsdotter, U.K.; Toftager, M.; Bentsen, P.; Kamper-Jørgensen, F.; Randrup, T.B. Factors influencing the use of green space: Results from a Danish national representative survey. Landsc. Urban Plan. 2010, 95, 130-137. [CrossRef]

49. Costanza, R.; d'Arge, R.; de Groot, R.; Farber, S.; Grasso, M.; Hannon, B.; Limburg, K.; Naeem, S.; O’Neill, R.V.; Paruelo, J.; et al. The value of the world's ecosystem services and natural capital. Nature 1997, 387, 253-260. [CrossRef]

50. Xie, G.; Zhang, C.; Zhang, L.; Chen, W.; Li, S. Improvement of the Evaluation Method for Ecosystem Service Value Based on Per Unit Area. J. Nat. Resour. 2015, 30, 1243-1254.

51. Heckert, M. Access and Equity in Greenspace Provision: A Comparison of Methods to Assess the Impacts of Greening Vacant Land. Trans. GIS 2013, 17, 808-827. [CrossRef]

52. Pham, T.-T.-H.; Apparicio, P.; Séguin, A.-M.; Landry, S.; Gagnon, M. Spatial distribution of vegetation in Montreal: An uneven distribution or environmental inequity? Landsc. Urban Plan. 2012, 107, 214-224. [CrossRef]

53. Nesbitt, L.; Meitner, M.J.; Girling, C.; Sheppard, S.R.J.; Lu, Y. Who has access to urban vegetation? A spatial analysis of distributional green equity in 10 US cities. Landsc. Urban Plan. 2019, 181, 51-79. [CrossRef]

54. Richards, D.R.; Passy, P.; Oh, R.R.Y. Impacts of population density and wealth on the quantity and structure of urban green space in tropical Southeast Asia. Landsc. Urban Plan. 2017, 157, 553-560. [CrossRef]

55. Ministry of Natural Resources of the People's Republic of China. Guiding Opinions on Cultivating and Developing Modern Metropolitan Areas. Available online: https:/ / www.ndrc.gov.cn/xxgk/zcfb/tz/201902/t20190221_962397.html (accessed on 17 February 2021).

56. Wu, L.F.; Kim, S.K. Health outcomes of urban green space in China: Evidence from Beijing. Sustain. Cities Soc. 2021, 65, 102604. [CrossRef]

57. Zhao, Z.; Gan, H.; Qian, X.; Leng, J.; Wang, Y.; Wu, P. Riverside Greenway in Urban Environment: Residents' Perception and Use of Greenways along the Huangpu River in Shanghai, China. Int. J. Environ. Res. Public Health 2021, 18, 1120. [CrossRef]

58. Zhang, J.; Yue, W.; Fan, P.; Gao, J. Measuring the accessibility of public green spaces in urban areas using web map services. Appl. Geogr. 2021, 126, 102381. [CrossRef]

59. Chen, J.; Cao, X.; Peng, S.; Ren, H. Analysis and Applications of GlobeLand30: A Review. ISPRS Int. J. Geo-Inform. 2017, 6, 230. [CrossRef]

60. Chen, F.; Chen, J.; Wu, H.; Hou, D.; Zhang, W.; Zhang, J.; Zhou, X.; Chen, L. A landscape shape index-based sampling approach for land cover accuracy assessment. Sci. China Earth Sci. 2016, 59, 2263-2274. [CrossRef]

61. Tatem, A.J. WorldPop, open data for spatial demography. Sci. Data 2017, 4, 170004. [CrossRef] [PubMed]

62. Lloyd, C.T.; Sorichetta, A.; Tatem, A.J. High resolution global gridded data for use in population studies. Sci. Data 2017, 4, 170001. [CrossRef] [PubMed]

63. Deininger, K.; Squire, L. A New Data Set Measuring Income Inequality. World Bank Econ. Rev. 1996, 10, 565-591. [CrossRef]

64. Barro, R.J. Inequality and Growth in a Panel of Countries. J. Econ. Growth 2000, 5, 5-32. [CrossRef]

65. Yang, J.; Huang, X.; Liu, X. An analysis of education inequality in China. Int. J. Educ. Dev. 2014, 37, 2-10. [CrossRef]

66. Asada, Y. Assessment of the health of Americans: The average health-related quality of life and its inequality across individuals and groups. Popul. Health Metrics 2005, 3, 7. [CrossRef] [PubMed]

67. Barr, L.M.; Pressey, R.L.; Fuller, R.A.; Segan, D.B.; McDonald-Madden, E.; Possingham, H.P. A New Way to Measure the World's Protected Area Coverage. PLoS ONE 2011, 6, e24707. [CrossRef]

68. Boyce, J.K.; Zwickl, K.; Ash, M. Measuring environmental inequality. Ecol. Econ. 2016, 124, 114-123. [CrossRef]

69. Kienast, F.; Degenhardt, B.; Weilenmann, B.; Wäger, Y.; Buchecker, M. GIS-assisted mapping of landscape suitability for nearby recreation. Landsc. Urban Plan. 2012, 105, 385-399. [CrossRef] 
70. Kimpton, A. A spatial analytic approach for classifying greenspace and comparing greenspace social equity. Appl. Geogr. 2017, 82, 129-142. [CrossRef]

71. World Bank. World Bank Country-Level Economic Indicators. Available online: https://data.worldbank.org/country/ (accessed on 3 July 2021).

72. Beninde, J.; Veith, M.; Hochkirch, A. Biodiversity in cities needs space: A meta-analysis of factors determining intra-urban biodiversity variation. Ecol. Lett. 2015, 18, 581-592. [CrossRef] [PubMed]

73. Chen, W.Y.; Hu, F.Z.H. Producing nature for public: Land-based urbanization and provision of public green spaces in China. Appl. Geogr. 2015, 58, 32-40. [CrossRef]

74. Ministry of Natural Resources of the People's Republic of China. Draft for Solicitation of Comments on "Regulations for the Compilation of Territorial and Spatial Planning of Metropolitan Areas". Available online: http://www.nrsis.org.cn/ seekPublicAdvice/pagePublishAdviceStdList/10000569 (accessed on 20 March 2021). 